\title{
Prediction of Brachiaria decumbens forage biomass using structural characteristics
}

\author{
Jefte A. de A. Conrado ${ }^{1 *}$, Marcos N. Lopes ${ }^{2}$, Magno J.D. Cândido ${ }^{1}$, Vitor H.M. Macedo ${ }^{3}$, \\ Valdson J. da Silva ${ }^{4}$, and Vitória G. Damasceno ${ }^{1}$
}

\begin{abstract}
${ }^{1}$ Universidade Federal do Ceará, Departamento de Zootecnia, Av. Mister Hull, 2977, Campus do Pici, CEP: 60356-000, Fortaleza, Ceará, Brasil. "Corresponding author (jefte_arnon@hotmail.com).

${ }^{2}$ Instituto Federal do Piauí, Campus Valença do Piauí, Av. Joaquim Manoel, s/n, Centro, Valença do Piauí, CEP: 64300-00, Valença do Piauí, Piauí, Brasil.

${ }^{3}$ Universidade Federal Rural da Amazônia, Av. Perimetral, 2501, CEP: 66077830, Belém, Para, Brasil.

${ }^{4}$ Universidade Federal Rural de Pernambuco, Av. Dom Manoel de Medeiros, s/n, Dois irmãos, CEP:62040370, Recife, Pernambuco, Brasil.
\end{abstract}

Received: 3 February 2021; Accepted: 29 April 2021; doi:10.4067/S0718-58392021000300467

\begin{abstract}
Tools that generate models with good biomass predictive capacity are essential to maintain the sustainability of production systems. The objective was to analyze the relationship between forage biomass and structural variables and generate models to predict total forage biomass (TFB) and green leaf blade biomass (GLB). Irrigated pastures of Brachiaria decumbens Stapf 'Basilisk' were kept under rotational stocking with sheep (Ovis aries L.) The TFB, GLB, leaf area index (LAI), height $(\mathrm{cm})$, and normalized difference vegetation index (NDVI) were evaluated. The experimental design was completely randomized with four replicates: ten and five cycles of defoliation management, respectively, were used to generate and validate the stages of the models. The best goodness of fit was obtained by nonlinear models for both TFB and GLB, which can be confirmed by high Spearman's correlations and significance $(\mathrm{P}<0.0001)$. The path analysis showed low collinearity (42.60) between NDVI, LAI, and height; the high determination coefficient $\left(\mathrm{R}^{2}\right)$ with values of 0.8421 and 0.7767 demonstrated their associations with TFB and GLB, respectively. Among the studied models to predict TFB and GLB, only exponentials using NDVI and power using LAI and height showed the best fit. In the validation stage, the models related to height exhibited the highest performance with 0.9531 (TFB) and 0.9638 (GLB) d-index, -2.3 (TFB) and -7.20 (GLB) bias, and 0.8532 (TFB) and 0.8932 (GLB) $\mathrm{R}^{2}$. Only nonlinear models using height $(\mathrm{cm})$ to predict TFB and GLB had the best practical application potential, thus ensuring efficiency in data collection.
\end{abstract}

Key words: Brachiaria decumbens, height, leaf area index, NDVI.

\section{INTRODUCTION}

Most of the meat and milk produced for worldwide consumption comes from animals raised in areas used exclusively for grazing (Silveira et al., 2018). The correct management of these species is the main measure to boost production growth and quality of these products, given that the correct monitoring of the pasture through practical and efficient measures and methodologies; this leads to the most appropriate management, which reduces the likelihood of pasture degradation and ensures the sustainability of the production systems (Tracy et al., 2015).

The genus Brachiaria represents $40 \%$ of all the forage species cultivated in Brazil and 'Basilisk' is the most widely diffused due to its high acceptability by animals, good nutritional value, high DM production (DM kg ha-1), and resistance to constant grazing (Rozalino Santos et al., 2011). 
The technologies currently used to monitor total forage biomass (TFB) and green leaf blade biomass (GLB) are indirect measures such as rulers, plates, and some elevation sensors; however, these tools were developed to meet the requirements of homogeneous pastures without taking into account their heterogeneity, either vertical or horizontal canopy (Trotter et al., 2010). They are also limited by the climatic and morphophysiological nature of the plant (Lim et al., 2015). Pedreira et al. (2014) indicated that it is important to use structural and physiological variables together or separately, which would be effective for predicting TFB and GLB. Stobbs (1973) highlighted the negative effect of canopy heterogeneity on animal performance which decreased the production indices of production systems. Souza et al. (2014) have already demonstrated higher animal performance when there was a greater supply of forage for the animals.

Given that efficient tools to quantify TFB and GLB in a practical way are complex and that the knowledge of these materials is fundamental to calculate the stocking rate, remote sensing (RS) has been gaining more acceptance in livestock farming because it characterizes the biomass at ground level in real time and provides values that help producers in their daily decision making (Andersson et al., 2017).

Active optical sensors (AOS) are examples of RS. They are not affected by atmospheric conditions because they use their own light source and also provide the normalized difference vegetation index (NDVI), which can be related to structural and physiological variables found in the area. The NDVI is based on spectral reflectance that differs significantly according to the region of the near infrared $(\lambda=700-1300 \mathrm{~nm})$ and the visible red range $(\lambda=550-700 \mathrm{~nm})$ of the electromagnetic spectrum (Andersson et al., 2017).

In the last $10 \mathrm{yr}$, these sensors have been mainly used in large crops (such as trees) and few studies (Trotter et al., 2010) have associated them to species with forage potential. This has made it difficult to obtain data that can generate accurate, practical, and applicable models for use in the daily management of production systems. In addition, it has been reported that there is saturation of this variable (NDVI) under conditions of moderate to high biomass production (Lim et al., 2015); however, this saturation point has not been identified and characterized.

Therefore, the objective was to analyze the relationship between both TFB and GLB and height, LAI, and NDVI, and subsequently generate prediction models of forage biomass for the forage species Brachiaria decumbens 'Basilisk' using NDVI, height, and LAI as independent variables.

\section{MATERIALS AND METHODS}

\section{Characterization of the study area and period}

The experiment was conducted at the Center of Teaching and Studies in Forage Crops, Department of Animal Science, Agricultural Sciences Center, Federal University of Ceará (NEEF/DZ/CCA/UFC), Fortaleza, Ceará, Brazil, from August 2018 to April 2020 (approximately 584 d). Data collection occurred over 2 yr, followed ethical standards, and was approved by the Animal Use Ethics Committee (Protocol No 80/17). Fortaleza (0345'47” S, 38³1'23”' W; 21 m a.s.1.) has a rainy tropical climate and Aw according to Köppen (Peel et al., 2007). Rainfall and temperature (maximum and minimum) data for the experimental and historical period of the area were collected at the UFC weather station located $0.5 \mathrm{~km}$ from the experimental area (Figure 1).

The species used in the experiment was Brachiaria decumbens Stapf 'Basilisk' (syn. Urochloa decumbens (Stapf) R.D. Webster 'Basilisk'). It was sown in a Yellow Argisol with a sandy texture (Santos et al., 2018), and an area of $1400 \mathrm{~m}^{2}$ was divided into 16 paddocks each measuring $12.5 \times 7 \mathrm{~m}\left(87.5 \mathrm{~m}^{2}\right)$ and equipped with fixed low pressure sprinkler irrigation (equivalent to an operating pressure $<2.0 \mathrm{kgf} \mathrm{cm}^{-2}$ ). The area has been grazed by Morada Nova sheep since 2001 .

Two soil sample collections were gathered (17 January 2018 and 15 January 2019) monitor fertility during the experimental period. They were collected at a $0-20 \mathrm{~cm}$ depth at ground level and sent to the UFC Soil Science Laboratory. The 2018 results revealed pH 6.80, $11.17 \mathrm{~g} \mathrm{~kg}^{-1}$ organic matter $(\mathrm{OM}), 285.0 \mathrm{mg} \mathrm{dm}^{-3} \mathrm{P}, 136.85 \mathrm{mg} \mathrm{dm}^{-3} \mathrm{~K}, 1.60 \mathrm{cmol}_{\mathrm{c}} \mathrm{dm}^{-3} \mathrm{Ca}^{2+}, 1.0 \mathrm{cmol}_{\mathrm{c}} \mathrm{dm}^{-3} \mathrm{Mg}^{2+}$, $0.20 \mathrm{cmol}_{\mathrm{c}} \mathrm{dm}^{-3} \mathrm{Al}^{3+}, 3.10 \mathrm{cmol}_{\mathrm{c}} \mathrm{dm}^{-3}$ sum of bases (SB), $3.60 \mathrm{cmol}_{\mathrm{c}} \mathrm{dm}^{-3}$ cation exchange capacity (CEC), and $86 \%$ base saturation (V). The 2019 results were $\mathrm{pH} 7.70,5.90 \mathrm{~g} \mathrm{~kg}^{-1} \mathrm{OM}, 26.0 \mathrm{mg} \mathrm{dm}^{-3} \mathrm{P}, 35.19 \mathrm{mg} \mathrm{dm}^{-3} \mathrm{~K}, 1.20 \mathrm{cmol}_{\mathrm{c}} \mathrm{dm}^{-3} \mathrm{Ca}^{2+}, 0.80$ $\mathrm{cmol}_{\mathrm{c}} \mathrm{dm}^{-3} \mathrm{Mg}^{2+}, 0.0 \mathrm{cmol}_{\mathrm{c}} \mathrm{dm}^{-3} \mathrm{Al}^{3+}, 3.0 \mathrm{cmol}_{\mathrm{c}} \mathrm{dm}^{-3} \mathrm{CEC}$, and $89 \% \mathrm{~V}$.

After evaluating soil analysis data, fertilization was carried out according to Alvarez et al. (1999) by applying $20 \mathrm{~kg} \mathrm{ha}^{-1}$ $\mathrm{P}_{2} \mathrm{O}_{5}$ and $200 \mathrm{~kg} \mathrm{ha}^{-1} \mathrm{~K}_{2} \mathrm{O}$ and using the single superphosphate and potassium chloride fertilizers, respectively. In addition, 30 and $40 \mathrm{~kg} \mathrm{ha}^{-1}$ of the commercial micronutrient formula FTE BR 12 were applied in 2018 and 2019, respectively. Nitrogen fertilization equivalent to $600 \mathrm{~kg} \mathrm{ha}^{-1} \mathrm{yr}^{-1}$ was also maintained; it was divided into two applications ( $1^{\text {st }}$ after the animals left and $2^{\text {nd }}$ in the middle of the plant growth cycle) with urea $\left(\mathrm{CH}_{4} \mathrm{~N}_{2} \mathrm{O}\right.$, with $\left.45 \% \mathrm{~N}\right)$ as the nutrient source. 
Figure 1. Precipitation, maximum and minimum temperatures (Max and Min. Temp.) of the experimental period (2018, 2019, and 2020) and historical (1989 to 2017) (Hist. Prec., Hist. Max. Temp., and Hist. Min. Temp.), respectively, for the experimental area.

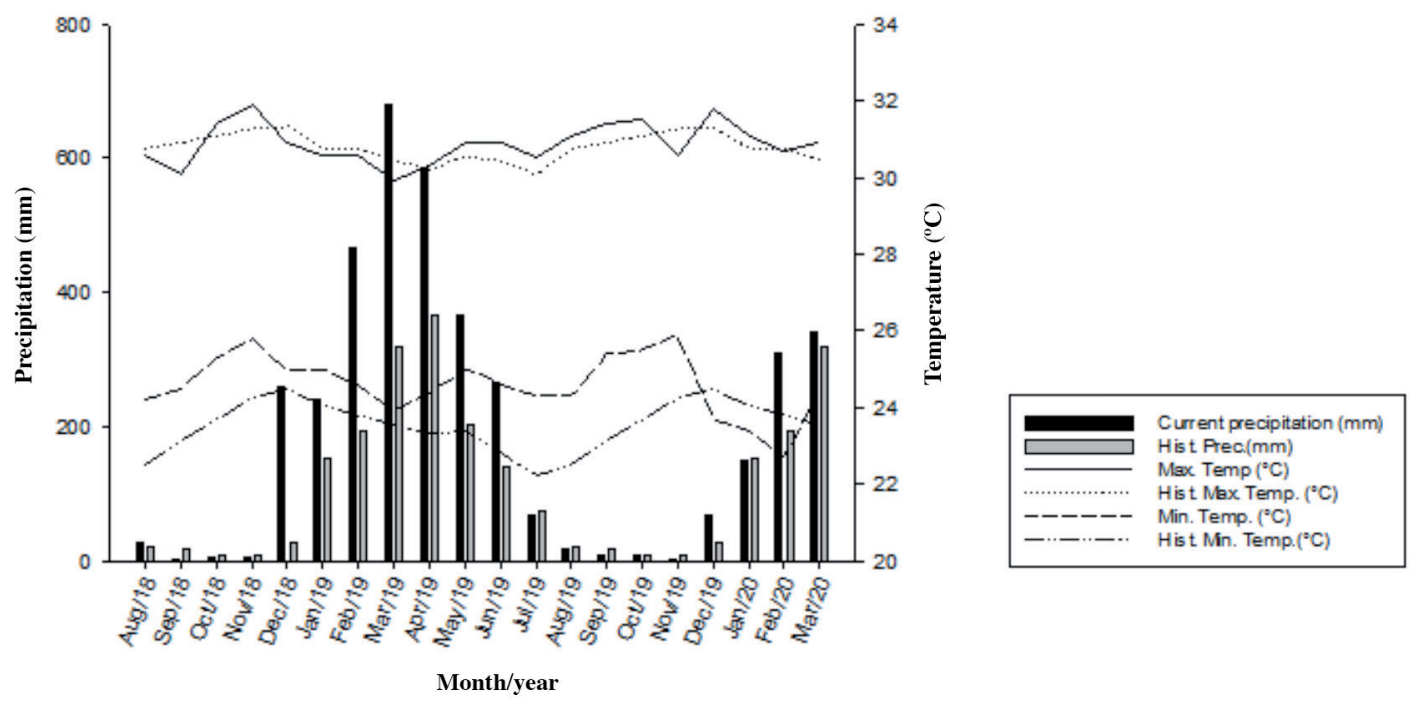

\section{Treatments and experimental design}

The experimental design was completely randomized with eight different treatments and four paddocks (replicates) per treatment. Pastures were managed based on $85 \%$ and 95\% light interception (LI) for a pre-grazing condition and 1.3 and 1.8 residual leaf area index (RLAI) under a residual condition. Data were grouped in the following order: $85 \%$ LI $\times 1.8$ RLAI residual, $85 \% \mathrm{LI} \times 1.3 \mathrm{RLAI}$ residual, 95\% LI $\times 1.8 \mathrm{RLAI}$ residual, 95\% LI $\times 1.3 \mathrm{RLAI}$ residual, $85 \% \mathrm{LI} \times 1.8$ RLAI pre-grazing, $85 \%$ LI × 1.3 RLAI pre-grazing, $95 \%$ LI $\times 1.8$ RLAI pre-grazing, and $95 \% \mathrm{LI} \times 1.3$ RLAI pre-grazing to obtain regression equations for the different treatment conditions.

\section{Evaluation of normalized difference vegetation index (NDVI), leaf area index (LAI), and height}

The NDVI values were measured with an active optical sensor (AOS) (GreenSeeker handheld crop sensor, Trimble, Sunnyvale, California, USA). It was developed to take readings between 0.6 to $1.2 \mathrm{~m}$ from the target distance with a field of view ranging from 25 to $50 \mathrm{~cm}$ (10" to 20") and a capacity of 1000 readings per second. The equipment is not affected by climatic conditions because it has emission diodes of its own radiation in the red bands $(650 \mathrm{~nm})$ and near infrared $(770 \mathrm{~nm})$. This index was proposed by Rouse et al. (1974) to monitor plant growth based on the spectral response of the canopy in the infrared ( $R_{\text {nir }}$, wavelengths between 700 to $1300 \mathrm{~nm}$ ) and red ( $R_{\text {red }}$, wavelengths between 550 to $700 \mathrm{~nm}$ ) bands. It is expressed as NDVI $=\left(\mathrm{R}_{\text {nir }}-\mathrm{R}_{\text {red }}\right) /\left(\mathrm{R}_{\text {nir }}+\mathrm{R}_{\text {red }}\right)$.

Height was measured with a retractable graduated rod $(\mathrm{cm})$ consisting of a $25 \mathrm{~mm}$ diameter PVC pipe, a type of sward stick (Barthram, 1986), and the measurement was taken on the curvature of the highest leaf.

Regarding the LAI variable, a canopy analyzer of photosynthetically active radiation (PAR)-LAI (AccuPAR LP-80, METER Group, Pullman, Washington, USA) was used to measure PAR and estimate LAI in a non-destructive way. A total of 15 points above and 15 points below the base of the canopy were taken between 10:00 and 12:00 $\mathrm{h}$ for each experimental unit.

\section{Determination of total forage biomass (TFB) and green leaf blade biomass (GLB)}

Biomass samples were collected (close to the soil surface) under both residual and pre-grazing conditions with a $42 \times 30 \mathrm{~cm}$ $\left(1260 \mathrm{~cm}^{2}\right)$ frame. Total material was weighed $(\mathrm{g})$ and fractionated and the leaf blade fraction was removed to record its weight (g); both weighings were recorded with a precision scale. The material was then placed in a forced air ventilation oven at $55^{\circ} \mathrm{C}$ until reaching constant weight (g); therefore, it was possible to quantify the total dry biomass (TDB) and GLB fractions. 


\section{Statistical analysis}

The application of the different treatments caused heterogeneity in the canopy structure and data distribution of the response variables, which were necessary to generate the models. Due to the lack of normality in the data and linearity in the relationship between the variables, Spearman's non-parametric correlation analysis was performed to verify the association between the variables. Path analysis was performed using Spearman's correlation to verify the cause-andeffect relationships between the variables.

There were 15 grazing/regrowth cycles during the experimental period and 70\% (10 first cycles) were used for correlation analysis and model generation, and the remaining $30 \%$ (five final cycles) were used for model validation.

The simple models between TFB and GLB, obtained with the relationship with NDVI, LAI, and height, were adjusted to first and second degree polynomial equations, exponential equation, and power. For each relationship, the model with the highest coefficient of determination $\left(\mathrm{R}^{2}\right)$ was chosen for the validation process. In addition to the simple models, multiple linear models were adjusted by considering the three predictor variables (NDVI, LAI, and height). The NDVI values showed a curvilinear relationship with biomass production between crops (Gu et al., 2013) and were also considered as an intermediate variable between LAI and biomass production because NDVI is also influenced by LAI. Therefore, multiple models were studied, which considered including or not NDVI and including quadratic NDVI with or without interaction effects between variables.

Model performance was evaluated by the d-index, which ranges from 0 to 1 ; a value of 1 indicates perfect accuracy and 0 indicates no accuracy (Willmott, 1981). The percent bias (PB) has an optimum value equal to zero: low magnitude values indicate good accuracy, positive values overestimate the model, and negative values underestimate the model. The regression analysis was performed between the observed and simulated values to verify model precision by calculating the determination coefficient and the accuracy of the model by checking the confidence intervals of the angular and linear coefficients of the linear regression equation.

The correlation analyses and adjustments of linear and nonlinear models were performed by the CORR, GLM, and NLIM procedures, respectively, with the SAS software (SAS Institute, Cary, North Carolina, USA). Path analysis was performed with the GENES statistical software (Cruz, 2013).

\section{RESULTS AND DISCUSSION}

Spearman's correlation analysis $\left(\mathrm{R}_{\mathrm{s}}\right)$ indicated a high degree of correlation between treatment measures and response variables (Table 1). High correlations were observed between the variable TFB and the estimation methods NDVI (0.8843), LAI (0.8758), and height (0.8931) all of which had a significance level of $\mathrm{P}<0.0001$. The GLB had a similar response with the NDVI (0.9380), LAI (0.9095), and height (0.8998) methods at a significance level of $\mathrm{P}<0.0001$.

The path analysis proposed by Wright (1921) made it possible to evaluate (by established diagrams) in more detail the interrelationships (cause and effect) between the variables (Figure 2).

When evaluating the presence and degree of multicollinearity, the analysis provided the value of 42.60 with a matrix determinant of 0.19 among the explanatory variables. The 42.60 value is considered as a weak degree of collinearity according to the Montgomery and Peck classification (Montgomery and Peck, 1981). The evaluation indicators are based on the variation of the determinant and the number of conditions ( $\mathrm{NC}=$ ratio between the largest and the smallest eigenvalue) of the tested matrices, that is, as the matrix determinant (correlation) between the analyzed variables approaches 0 , the value ranking ( $\mathrm{NC}<100$, weak; $100<\mathrm{NC}<1000$, moderate to strong; $\mathrm{NC}>1000$, severe) becomes tighter. Rodrigues et al. (2010) described that the variances linked to the factors that estimate the path coefficient generate unreliable values in the presence of multicollinearity. Thus, the estimated parameters assume values that are inconsistent with the biological factor under study, which was not observed in the present study.

The path analysis of the 10 cycles used to generate the models exhibited residual effects (E) for TFB and GLB of 0.3973 and 0.4725 , respectively, while the determination coefficients $\left(\mathrm{R}^{2}\right)$ were 0.8421 and 0.7767 , respectively.

Higher TFB and GLB relationships were observed with the NDVI and height methods; values for NDVI were 0.3284 and 0.3970 , respectively, and height values were 0.4080 and 0.3039 , respectively. The LAI showed lower values when compared to the NDVI and height, and showed values of 0.2080 and 0.2064 for TFB and GLB, respectively. However, there was a strong relationship between LAI and height for TFB (0.9325) and GLB (0.9325) (Figure 2). Lower values 
Table 1. Spearman's correlation coefficient $\left(R_{s}\right)$ between variables TFB, GLB, NDVI, LAI, and height of the species Brachiaria decumbens 'Basilisk' managed for 584 days.

\begin{tabular}{lccccc}
\hline Variable & TFB & GLB & NDVI & LAI & Height \\
\hline TFB & - & $0.9450^{* *}$ & $0.8843^{* *}$ & $0.8758^{* *}$ & $0.8931^{* *}$ \\
GLB & & - & $0.9380^{* *}$ & $0.9095^{* *}$ & $0.8998^{* *}$ \\
NDVI & & - & $0.9515^{* *}$ & $0.9277^{* *}$ \\
LAI & & & - & $0.9539^{* *}$ \\
Height & & & & & - \\
\hline
\end{tabular}

**Significant correlation coefficient $(\mathrm{P}<0.0001)$.

TFB: Total forage biomass; GLB: green leaf blade biomass; NDVI: normalized difference vegetation index; LAI: leaf area index ( $\mathrm{n}=321$ observations).

Figure 2. Path analysis diagram to predict TFB $(A)$ and GLB $(B)$ in response to the different methodologies (NDVI, LAI, and height) proposed to quantify their variations in Brachiaria decumbens 'Basilisk' managed under grazing for $584 \mathrm{~d}$.

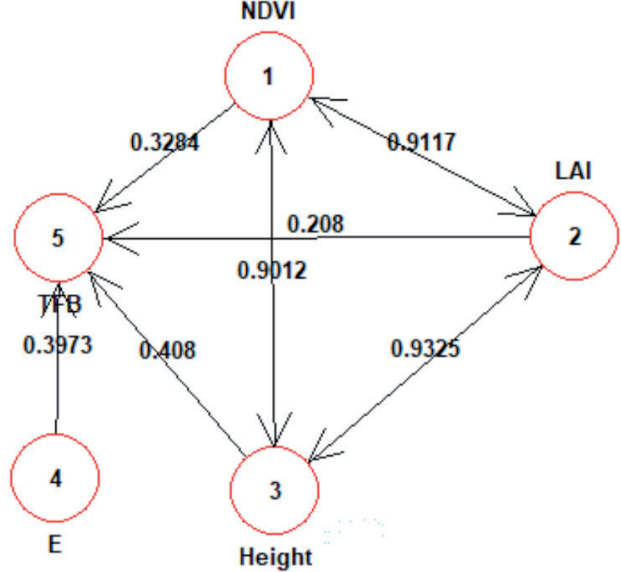

(A)

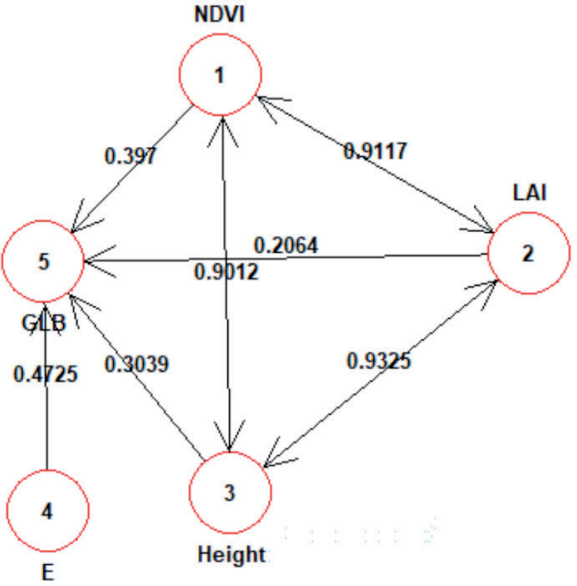

(B)

TFB: Total forage biomass; GLB: green leaf blade biomass; NDVI: normalized difference vegetation index; LAI: leaf area index.

are possible because the constituents of the correlation can promote values on a larger scale than the evaluated unit and also less than -1 (Rodrigues et al., 2010). This ccould be associated with the rapid stem fraction development and leaf area reduction of the pastures when reaching critical LAI, contributing to decreasing the quality of light that reaches the interior of the canopy (Shafiq et al., 2021).

According to Cruz and Carneiro (2012), when a parameter correlates on different scales with other parameters that could be included in the model, additional care is necessary (if multiple use is chosen) because increasing it can cause further problems to the final model, such as the complexity of collecting the variable without increasing the reliability of the result (response variable). The simple models based on the highest $\mathrm{R}^{2}$ values were those generated by nonlinear regression methods. For the relationship of both TFB and GLB with NDVI, the exponential model had the best fit (Figures 3A, 3D), while it was the power model for LAI and height (Figures 3B, 3C, 3E, 3F). As for TFB, the model involving height, which also had the best fit, showed the highest performance indices in the validation process with a $0.9531 \mathrm{~d}$-index, -2.3 percent bias, and 0.8532 determination coefficient (Figure 4C). As for GLB, the height model showed the highest d-index value (0.9638), the lowest percent bias (-7.20), and one of the lowest determination coefficient values (0.8932) (Figure 4F).

Studies (Gu et al., 2013; Xia et al., 2016; Wu et al., 2020) have already indicated the possibility of saturation in the functions of the generated models, mainly in response to biophysical and physiological variables of the canopy, which is the case for the NDVI. They therefore established nonlinear functions such as the best fit. The main advantages of these models when compared with linear models are parsimony, interpretability, prediction, and robustness (mainly outside the observed data range) because they are able to group a wide variety of mean functions that are different from polynomial (linear) models requiring more parameters (Archontoulis and Miguez, 2015). The height variable has been used as the main methodology mostly for the practicality of its collection and its correlation with TFB, especially in more homogeneous 
pastures (Mezzalira et al., 2014). Another variable is LAI, which Watson (1947) defined as the unilateral area of leaf blades per unit of soil with the main function of producing photoassimilates. Therefore, these two variables could potentially be used together as a measure that comprises the model to improve pasture management because they are closely related to plant growth; however, its practicality must be evaluated (Congio et al., 2018). It is worth noting that defoliation events by animals do not happen in a uniform manner and contribute to structural changes in the canopy, especially for grasses in a tropical climate. According to Rozalino Santos et al. (2011), canopy heterogeneity caused by grazing directly reflects the accuracy of the chosen method for estimating TFB; it causes different coefficients of variation (CV) between them, which can make it difficult to estimate biomass production in an area where there is heterogeneity of canopy height. The NDVI measurements with AOS to estimate biomass production can be an alternative to solve this problem.

Figure 3. Generation of nonlinear models to quantify TFB and GLB using NDVI (A and D, respectively), LAI (B and E, respectively), and height ( $\mathrm{C}$ and $\mathrm{F}$, respectively) under different treatments of Brachiaria decumbens 'Basilisk' grazed by sheep and rotational stocking management.
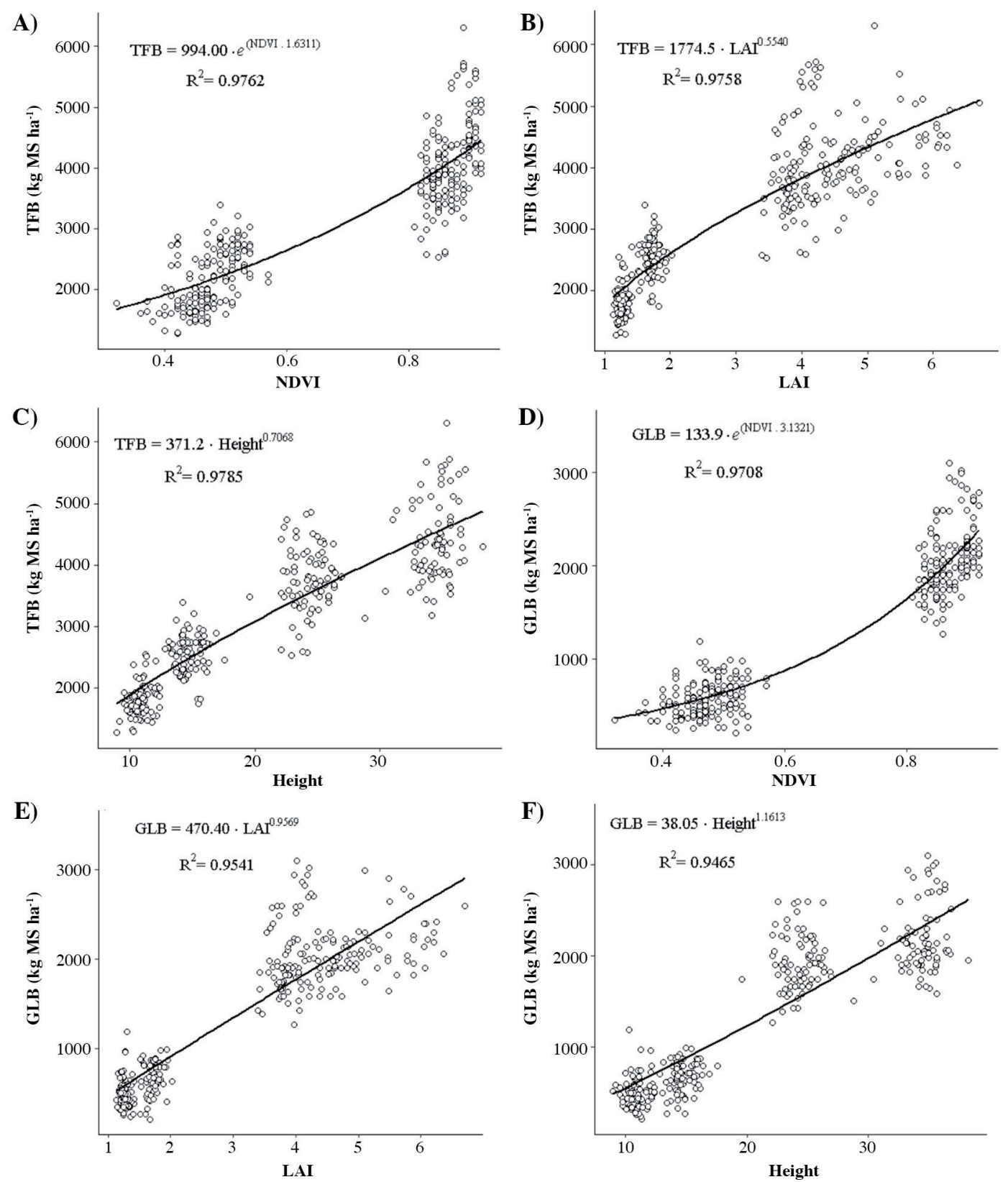

TFB: Total forage biomass; GLB: green leaf blade biomass; NDVI: normalized difference vegetation index; LAI: leaf area index. 
Figure 4. Validation of nonlinear models used to determine TFB and GLB resulting from the association with NDVI (A and D, respectively), LAI (B and E, respectively), and height ( $C$ and $F$, respectively) under different treatments of Brachiaria decumbens 'Basilisk' grazed by sheep and rotational stocking management.
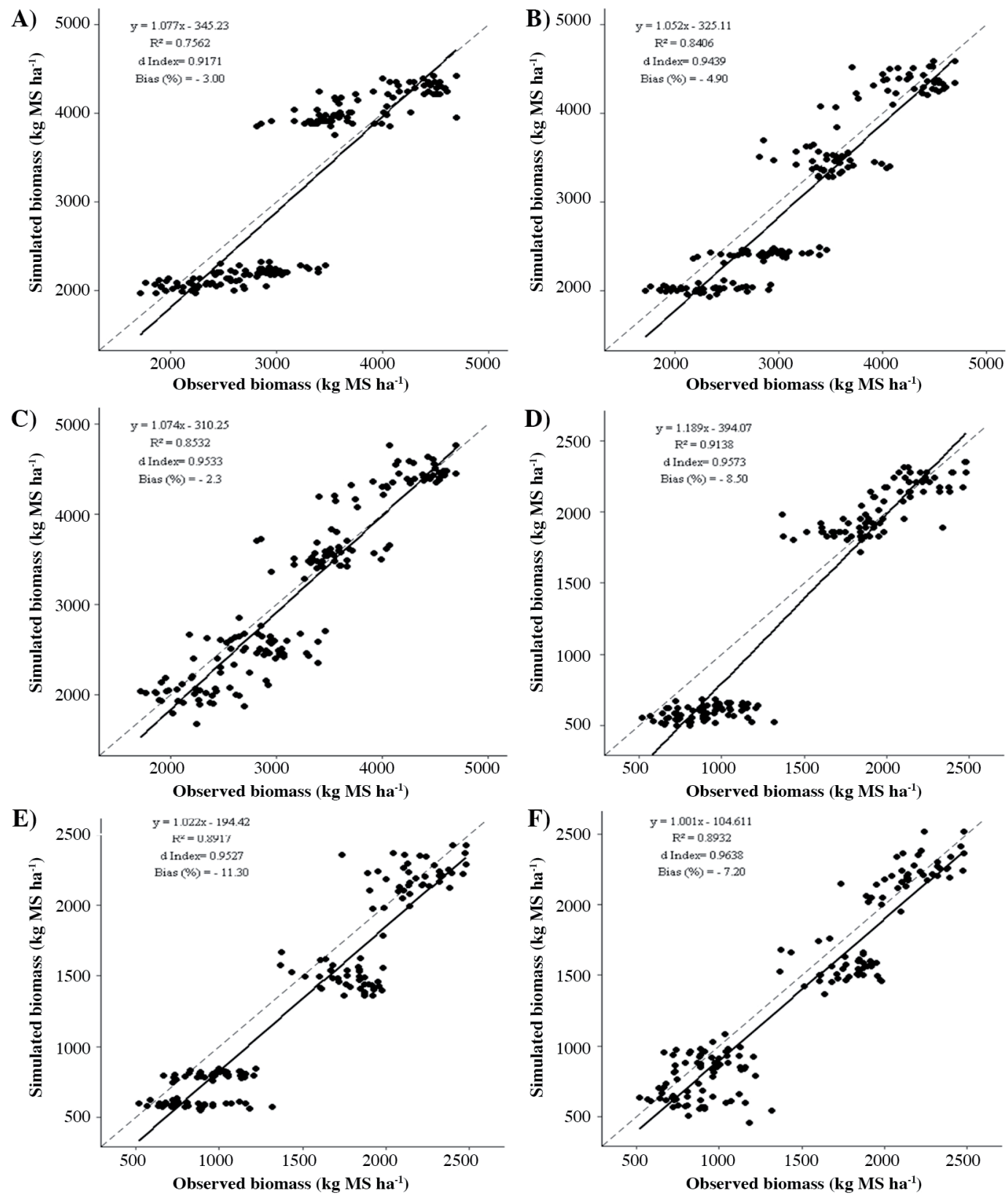

TFB: Total forage biomass; GLB: green leaf blade biomass; NDVI: normalized difference vegetation index; LAI: leaf area index.

It can be inferred from the relationship between NDVI and biomass (Figures 3A, 3D) that NDVI is present in saturation. This limitation comes from the shift of the reflection away from the plant growth wavelengths, thus increasing the light reflected in the near infrared and making the normalization of NDVI reflectance less sensitive to variations in this region when it is higher than red. In addition, green vegetation has high absorption in the red spectrum region (approximately $670 \mathrm{~nm}$ ) with low reflectance (3\% to 5\%), whereas the levels are higher in the infrared region (40\% to $60 \%)$. The biomass production process promotes spectral differentiation with a change in structural characteristics (such as increased LAI) and has the potential to alter the quality of the reflected light, which shows its close relationship with NDVI (Liu and Zhiming, 2012). One of the advantages of obtaining NDVI values with AOS, compared with passive optical sensors is its efficiency 
in quantifying the variable (NDVI) under unfavorable environmental conditions such as cloudiness (Rahetlah et al., 2014). The operating principle of these GreenSeeker AOS is that they calculate the NDVI index through the reflectance of an internal microprocessor adapted to the sensor, thus preventing environmental influences. Other studies (Grohs et al., 2009) have indicated the potential of this equipment to validate and generate algorithms that are able to determine the nutritional status, grain yield, and productivity of agricultural crops such as wheat, barley, and corn.

Aquino et al. (2018) demonstrated that remote sensing (RS) has been an important tool worldwide to identify locations with some type of manipulation, and it has been essential in the planning of the developed activity. Therefore, the use of NDVI in the pasture management process can be an important tool.

Lyu et al. (2021) described the importance of generating multiple models that could be compared to develop accurate evaluation measures that could contribute to the ecological aspects and sustainable economic development of pasture areas. Cargnelutti Filho and Toebe (2020) highlighted that when variables exhibit high correlations (as in the present research, Table 1), multiple models can generate adequate precision indicators and reduce their uncertainty coefficient. However, their applicability is worth noting.

Among the multiple linear models, the TFB-M1 model showed the best performance to predict TFB. This was the simplest model; it only included LAI and height as predictive variables without the effect of interaction (Table 2). Although it did not exhibit one of the best adjustments $\left(\mathrm{r}^{2}=0.8039\right)$ and percent bias, it had the highest $\mathrm{d}$-index $(0.9475)$ and determination coefficient $\left(\mathrm{R}^{2}=0.8471\right)$ values in the validation process among multiple models (Figure 5A). The GLB-M3 model had the best performance among the multiple linear models to predict GLB (Figure 6C). This model also had no interaction effect, but it had the three predictive variables in its construction (NDVI, LAI, and height) (Table 2).

In general, GLB prediction models showed higher d-index and determination coefficient values and lower percent bias values compared with the TFB prediction models. The percent bias was negative in all the models, which indicates that they all underestimated the biomass production values. The simple models based on height had the best performance for both TFB and GLB. However, most of the multiple linear models, for both TFB and GLB, performed better than the simple models based on the LAI and NDVI. This demonstrates that choosing only one variable of indirect biomass estimation (e.g., height or LAI) to establish the carrying capacity (CC) of the area may not be sufficient to obtain more accurate predictions. Despite this, the differences between all the models were not large, the adjustments based on $\mathrm{R}^{2}$ ranged from 0.8039 to 0.9785 , the d-index from 0.9170 to 0.9638 , the percent bias from $-11.2 \%$ to $-2.3 \%$, and the validation determination coefficient from 0.7562 to 0.9172 . All of these values indicate good performance for all models. In addition to their performance, the characteristics of the location where they are used and the availability of measurement tools can determine which application is chosen.

Table 2. Generation of multiple linear models used to determine TFB and GLB associated with LAI, height, and NDVI under different treatments of Brachiaria decumbens 'Basilisk' grazed by sheep and under rotational stocking management.

\begin{tabular}{|c|c|c|}
\hline Name & Equation & $\mathrm{R}^{2}$ \\
\hline \multicolumn{3}{|c|}{ Total forage biomass (TFB, $\mathrm{kg} \mathrm{DM} \mathrm{ha}^{-1}$ ) } \\
\hline TFB-M1 & $\mathrm{TFB}=937.85+185.26 * \mathrm{LAI}+77.958 *$ Height & 0.8039 \\
\hline TFB-M2 & TFB $=-55.41+553.11 *$ LAI $+135.22 *$ Height $-17.00 *$ LAI $*$ Height & 0.8269 \\
\hline TFB-M3 & $\mathrm{TFB}=250.35-33.15 * \mathrm{LAI}+66.46 *$ Height $+2361.52 * \mathrm{NDVI}$ & 0.8200 \\
\hline TFB-M4 & $\mathrm{TFB}=977.30-33.97 * \mathrm{LAI}+65.45 *$ Height $+1794.88 * \mathrm{NDVI}^{2}$ & 0.8182 \\
\hline TFB-M5 & $\begin{array}{c}\text { TFB }=-4694.37+3952.05 * \mathrm{LAI}+346.89 * \text { Height }-192.83 * \mathrm{LAI} * \text { Height }+ \\
5611.01 * \mathrm{NDVI}-3874.47 * \mathrm{LAI} * \mathrm{NDVI}-234.7 * \text { Height } * \mathrm{NDVI}+196.03 * \mathrm{LAI} * \text { Height } * \mathrm{NDVI} \\
\mathrm{TFB}=-2692.93+2589.06 * \mathrm{LAI}+243.94 * \text { Height }-113.96 * \mathrm{LAI} * \text { Height }+\end{array}$ & 0.8455 \\
\hline TFB-M6 & $3,892.51 * \mathrm{NDVI}^{2}-2682.05 * \mathrm{LAI} * \mathrm{NDVI}^{2}-136.10 *$ Height $* \mathrm{NDVI}^{2}+121.99 * \mathrm{LAI} *$ Height $* \mathrm{NDVI}^{2}$ & 0.8456 \\
\hline \multicolumn{3}{|c|}{ Green leaf blade biomass (GLB, $\left.\mathrm{kg} \mathrm{DM}_{\mathrm{ha}}{ }^{-1}\right)$} \\
\hline GLB-M1 & $\mathrm{GLB}=-161.89+279.45 * \mathrm{LAI}+30.61 *$ Height & 0.8386 \\
\hline GLB-M2 & GLB $=-1011.17+593.98 *$ LAI $+79.57 *$ Height $-14.54 *$ LAI $*$ Height & 0.8726 \\
\hline GLB-M3 & GLB $=-991.79-15.81 *$ LAI $+16.74 *$ Height $+285.64 *$ NDVI & 0.8862 \\
\hline GLB-M4 & GLB $=-109.32-12.67 * \mathrm{LAI}+13.96 *$ Height $+2391.73 * \mathrm{NDVI}^{2}$ & 0.8901 \\
\hline & GLB $=107.76+395.95 *$ LAI $+24.59 *$ Height $-38.15 *$ LAI $*$ Height - & \\
\hline GLB-M5 & $\begin{array}{c}1344.49 * \mathrm{NDVI}-319.84 * \mathrm{LAI} * \mathrm{NDVI}+91.07 * \text { Height } * \text { NDVI }+18.37 * \mathrm{LAI} * \text { Height } * \text { NDVI } \\
\text { GLB }=-241.77+412.32 * \mathrm{LAI}+36.81 * \text { Height }-22.06 * \text { LAI } * \text { Height }-\end{array}$ & 0.8948 \\
\hline GLB-M6 & $593.14 * \mathrm{NDVI}^{2}+235.16 * \mathrm{LAI} * \mathrm{NDVI}^{2}+72.33 *$ Height $* \mathrm{NDVI}^{2}+3.47 * \mathrm{LAI} *$ Height $* \mathrm{NDVI}^{2}$ & 0.8945 \\
\hline
\end{tabular}

$\mathrm{R}^{2}$ : coefficient of determination; TFB: total forage biomass; GLB: green leaf blade biomass; NDVI: normalized difference vegetation index; LAI: leaf area index. 
Figure 5. Validation of multiple models (Table 2), TFB-M1 (A), TFB-M2 (B), TFB-M3 (C), TFB-M4 (D), TFB-M5 (E), and TFB-M6 (F) to quantify TFB associatd with LAI, height, and NDVI under different treatments of Brachiaria decumbens 'Basilisk' grazed by sheep and rotational stocking management.


TFB: Total forage biomass; LAI: leaf area index; NDVI: normalized difference vegetation index. 
Figure 6. Validation of multiple models (Table 2), GLB-M1 (A), GLB-M2 (B), GLB-M3 (C), GLB-M4 (D), GLB-M5 (E), and GLB-M6 (F) to quantify GLB associated with LAI, height, and NDVI under different treatments of Brachiaria decumbens 'Basilisk' grazed by sheep and rotational stocking management.
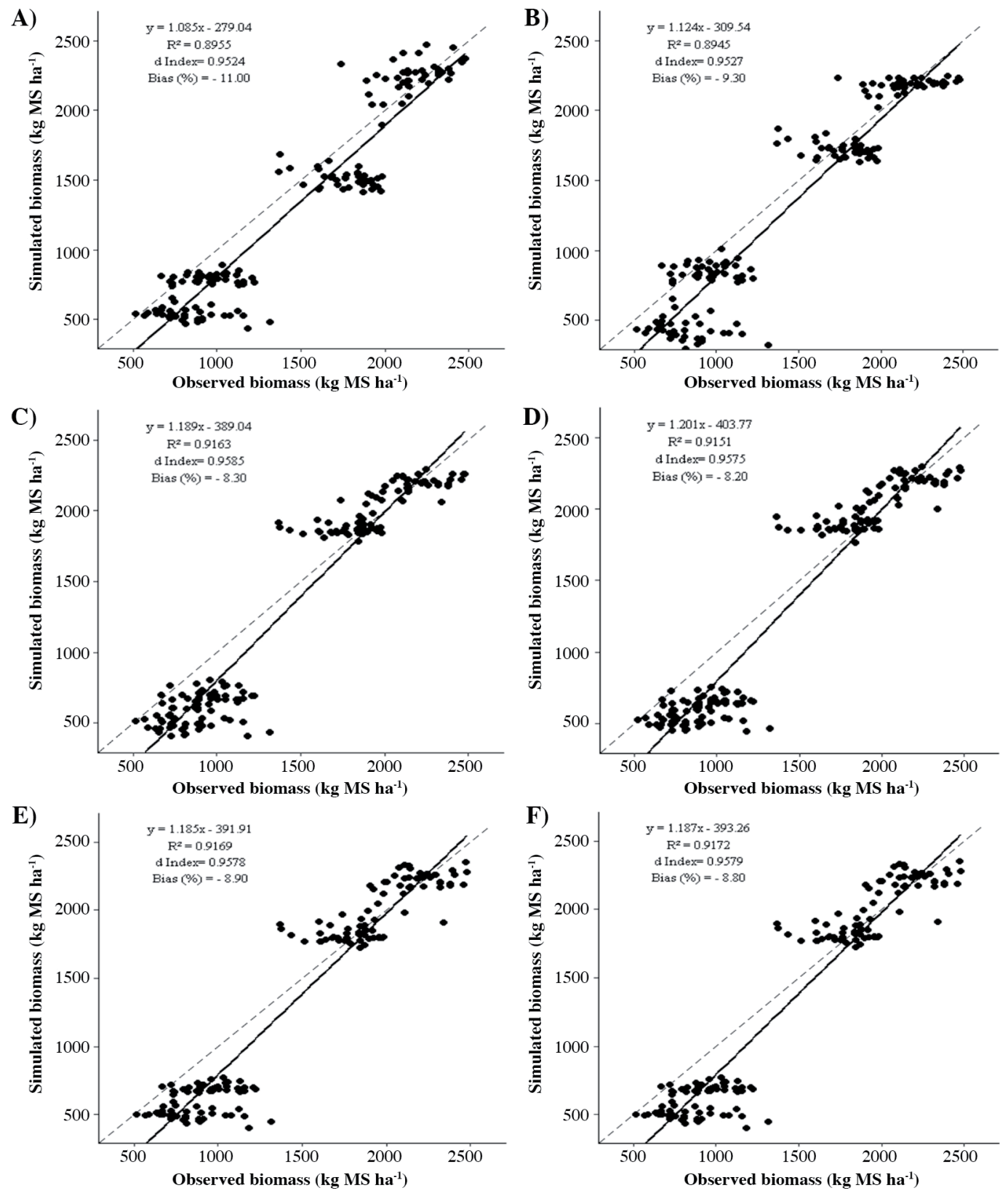

GLB: Green leaf blade biomass; LAI: leaf area index; NDVI: normalized difference vegetation index. 


\section{CONCLUSIONS}

The simple nonlinear model between total forage biomass (TFB) and green leaf blade biomass (GLB) with height had the best performance among the models. However, multiple linear models can also be used to efficiently predict biomass production of the species Brachiaria decumbens 'Basilisk' under grazing management.

The normalized difference vegetation index (NDVI) methodology can be used mainly in the canopy of forage plants with a leaf area index (LAI) value up to 4.0 , after which the saturation process begins.

The LAI has the potential to improve multiple linear models; however, it is more complex and makes the model less applicable at the farm level, especially for managers with little experience and training.

\section{ACKNOWLEDGEMENTS}

The authors thank the Coordination for the Improvement of Higher Education Personnel (CAPES) for granting a doctoral scholarship and the Federal University of Ceará (UFC) and the Center of Teaching and Studies in Forage Crops (NEEF) for all the structural and technological support to develop this research.

\section{REFERENCES}

Alvarez, V.V.H., Novais, R.F. de, Barros, N.F. de, Cantarutti, R.B., e Lopes, A.S. 1999. Interpretação dos resultados das análises de solos. p. 25-32. In Ribeiro, A.C., Guimarães, P.T.G., e Alvarez, V.H. (eds.) Recomendações para o uso de corretivos e fertilizantes em Minas Gerais: 5a aproximação. Comissão de Fertilidade do Solo do Estado de Minas Gerais, Viçosa, Brasil.

Andersson, K., Trotter, M., Robson, A., Schneider, D., Frizell, L., Saint, A., et al. 2017. Estimating pasture with active optical sensors. Advances in Animal Biosciences 8:754-757. doi:10.1017/S2040470017000838.

Aquino, D.N., Rocha Neto, O.C., Moreira, M.A., Teixeira, A.S., and Andrade,E.M. 2018. Use of remote sensing to identify areas at risk of degradation in the semi-arid region. Revista Ciência Agronômica 49:420-429. doi:10.5935/1806-6690.20180047.

Archontoulis, S.V., and Miguez, F.E. 2015. Nonlinear regression models and applications in agricultural research. Agronomy Journal 107:786-798. doi:10.2134/agronj2012.0506.

Barthram, G.T. 1986. Experimental techniques - the HFRO sward stick. Biennial Report of the Hill Farming Research Organisation 1984-85. p. 29-30. Alcock, M.M. (ed.) Hill Farming Research Organisation, Penicuik, Midlothian, UK.

Cargnelutti Filho, A., and Toebe, M. 2020. Reference sample size for multiple regression corn. Pesquisa Agropecuária Brasileira 55:e01400. doi:10.1590/S1678-3921.pab2020.v55.01400.

Congio, G.F.S., Batalha, C.D.A., Chiavegato, M.B., Berndt, A., Oliveira, P.P.A., Frighetto, R.T.S., et al. 2018. Strategic grazing management towards sustainable intensification at tropical pasture-based dairy systems. Science of the Total Environment 636:872-880. doi:10.1016/j.scitotenv.2018.04.301.

Cruz, C.D. 2013. A software package for analysis in experimental statistics and quantitative genetics. Acta Scientiarum 35:271276. doi:doi.org/10.4025/actasciagron.v35i3.21251.

Cruz, C.D., e Carneiro, P.C.S. 2012. Modelos biométricos aplicados ao melhoramento genético. v. 2. Editora UFV, Viçosa, Brasil.

Grohs, D.S., Bredemier, C., Mundstock, C.M., e Poletto, N. 2009. Modelo para estimativa do potencial produtivo em trigo e cevada por meio do sensor greenseeker. Engenharia Agrícola 29:101-112. doi:10.1590/S0100-69162009000100011.

Gu, Y., Wylie, B., Howard, D.M., Phuyal, K.P., and Ji, L. 2013. NDVI saturation adjustment: A new approach for improving cropland performance estimates in the Greater Platte River Basin, USA. Ecological Indicators 30:1-6. doi:10.1016/j.ecolind.2013.01.041.

Lim, J., Kawamura, K., Lee, H.J., Yoshitoshi, R., Kurokawa, Y., Tsumiyama, Y., et al. 2015. Evaluating a hand-help cropmeasuring device for estimating the herbage biomass, leaf área index and crude protein content in na Italian ryegrass field. Grassland Science 61:101-108. doi:10.1111/grs.12083.

Liu, F.Q.Q., and Zhiming, Z. 2012. A novel dynamic stretching solution to eliminate saturation effect in NDVI and its application in drought monitoring. Chinese Geographical Science 22:683-694. doi:10.1007/s11769-012-0574-5.

Lyu, X., Li, X., Gong, J., Li, S., Dou, H., Dang, D., et al. 2021. Remote-sensing inversion method for aboveground biomass of typical steppe in Inner Mongolia, China. Ecological Indicators 120:106883. doi:10.1016/j.ecolind.2020.106883.

Mezzalira, J.C., Carvalho, P.C.F., Fonseca, L., Bremm, C., Cangiano, C., Gonda, H.L., et al. 2014. Behavioural mechanisms of intake rate by heifers grazing swards of contrasting structures. Applied Animal Behaviour Science 153:1-9. doi:10.1016/j.applanim.2013.12.014. 
Montgomery, D.C., and Peck, E.A. 1981. Introduction to linear regression analysis. John Wiley \& Sons, New York, USA.

Pedreira, B., Pedreira, C.G.S., and Lara, M.S. 2014. Leaf age, leaf blade portion and light intensity as determinants of leaf photosynthesis in Panicum maximum Jacq. Grassland Science 61:45-49. doi:10.1111/grs.12080.

Peel, M.C., Finlayson, B.L., and McMahon, T.A. 2007. Updated world map of the Köppen-Geiger climate classification. Hydrology and Earth System Sciences 11:1633-1644. doi:10.5194/hess-11-1633-2007.

Rahetlah, B.V., Salgado, P., Andrianarisoa, B., Tillard, E., Razafindrazaka, H., Le Mézo, L., et al. 2014. Relationship between normalized difference vegetation index (NDVI) and forage biomass yield in the Vakinankaratra region, Madagascar. Livestock Research for Rural Development 26:95.

Rodrigues, G.B., Marin, B.G., Silva, D.J.H., Mattedi, A.P., e Almeida, V.S. 2010. Análise de trilha de componentes de produção primários e secundários em tomateiro do grupo salada. Pesquisa Agropecuária Brasileira 45:155-162. doi:10.1590/S0100-204X2010000200006.

Rouse, J.W., Haas, H.R., Deering, D.W., Schell, J.A., and Harlan, J.C. 1974. Monitoring the vernal advancement and retrogradation (greenwave effect) of natural vegetation. NASA/GSFC Type III Final Report. Goddard Space Flight Center, Greenbelt, Maryland, USA.

Rozalino Santos, M.E., Fonseca, D.M., Braz, T.G.S., Silva, S.P., Gomes, V.M., e Silva, G.P. 2011. Características morfogênicas e estruturais de perfilhos de capim-braquiária em locais do pasto com alturas variáveis. Revista Brasileira de Zootecnia 40:535-542. doi:10.1590/S1516-35982011000300010.

Santos, H.G. dos, Jacomine, P.K.T., Anjos, L.H.C. dos, Oliveira, V.A. de, Oliveira, J.B. de, Lumbreras, J.F., et al. (eds.) 2018 Sistema brasileiro de classificação de solos. 5a ed. Embrapa Solos, Brasilia DF, Brasil.

Shafiq, I., Hussain, S., Raza, M.A., Iqbal, N., Asghar, M.A., Raza, A., et al. 2021. Crop photosynthetic response to light quality and light intensity. Journal of interative Agriculture 20:4-23. https://doi.org/10.1016/S2095-3119(20)63227-0.

Silveira, R.M.F., Vasconcelos, A.M., Araújo, J.M., Ferreira, J.B., Oliveira, P.G.A., e Brito, T.M. 2018. Influência dos índices reprodutivos na produção leite de vacas mestiças criadas no litoral Cearense. Revista Agropecuária Científica do Semiárido 14:117-122. doi:10.30969/acsa.v14i2.938.

Souza, J., Batistel, F., Ticiani, E., Sandri, E.C., Pedreira, C.G.S., and Oliveira, D.E. 2014. Green leaf allowance and dairy ewe performance grazing on tropical pasture. Journal of Animal Science 92:2708-2715. doi:10.2527/jas.2013-7238.

Stobbs, T.H. 1973. The effect of plant structure on the intake of tropical pastures. I. Variation in bite size of grazing cattle. Australian Journal of Agricultural Research 24:809-819. doi:10.1071/AR9730809.

Tracy, B.F., Schlueter, D.H., and Flores, J.P. 2015. Conditions that favor clover establishment in permanente grass swards. Grassland Science 61:34-40. doi:10.1111/grs.12075.

Trotter, M.G., Lamb, D.W., Donald, G.E., and Schneider, D.A. 2010. Evaluating an active optical sensor for quantifying and mapping green herbage mass and growth in a perennial grass pasture. Crop and Pasture Science 61:389-398. doi:10.1071/CP10019.

Watson, D.J. 1947. Comparative physiological studies in the growth of field crops. I. Variation in net assimilation rate and leaf area between species and varieties, and within and between years. Annals of Botany 11:41-76.

Willmott, C.J. 1981. On the validation of models. Physical Geography 2:184-194. doi:10.1080/02723646.1981.10642213.

Wright, S. 1921. Correlation and causation. Journal of Agricultural Research 20:557-585.

Wu, T., Feng, F., Lin, Q., and Bai, H. 2020. A new temporal prediction method of grazing pressure based on normalized difference vegetation index and precipitation using nonlinear autoregressive with exogenous input networks. Grassland Science 66:116-123. doi:10.1111/grs.12262.

Xia, T., Miao, Y., Wu, D., Shao, H., Khosla, R., and Mi, G. 2016. Active optical sensing of spring maize for in-season diagnosis of nitrogen status based on nitrogen nutrition index. Remote Sensing 8:605. doi:10.3390/rs8070605. 